\title{
FOOD COMBINING: Sehat Secara Natural
}

\author{
Oleh: Amar Ma'ruf
}

\section{Mengenal Food Combining}

Keseimbangan asupan makanan menjadi kunci penting untuk menjaga kesehatan tubuh sekaligus menghindari ketakutan kelebihan berat badan (obesitas). Beragam jenis diet dan pola makan sengaja diatur agar memenuhi faedah semestinya dari aktifitas makan. Beberapa unsur gizi yang diperlukan tubuh seperti pati, protein, asam, dan lemak menghendaki kondisi yang seimbang agar memberikan manfaat bagi tubuh. Sekiranya salah satu unsur mendominasi tubuh secara telak, maka akan terjadi gangguan. Misalnya jika seseorang kelebihan karbohidrat, ia berisiko tinggi menderita obesitas dan diabetes. Bagi sebagian besar kalangan, tentu jadi masalah serius. Cemas dengan kegemukan dan ancaman serius bagi kelangsungan hidup.

Dari beragam pola makan yang ditawarkan, baik atas kebiasaan yang gampang kita temui maupun anjuran-anjuran para ahli, food combining menjadi salah satu pilihan. Pola makan ini dilakukan dengan mengatur keseimbangan kombinasi menu, frekuensi, jumlah asupan, serta kedisiplinan. Penerapannya memisah-misahkan makanan sebagai upaya untuk menyelaraskan unsur-unsur gizi yang diperlukan tubuh. Food combining mengharapkan kerjasama antar unsur gizi. Mengapa harus dipisah-pisahkan? Alasannya, kerjasama antar unsur gizi tidak seketika terjadi saat makanan masuk dalam perut, melainkan setelah makanan terurai menjadi komponen-komponen yang sangat renik.

Kendati terbukti menuai banyak manfaat, rupanya masih banyak para ahli tidak menyetujui konsep food combining. Mereka mengatakan bahwa food combining adalah metode yang absurd alias tidak masuk akal. Alasannya karena setiap makanan secara alamiah sudah mengandung beberapa unsur sekaligus yang bisa dicerna bersamaan dalam pencernaan manusia. Padahal jika diibaratkan seseorang yang melakukan rutinitas kesehariannya, beberapa pekerjaan justru lebih efektif jika dilakukan bergantian, bukan bersamaan. Tuntas pekerjaan satu, lanjut ke pekerjaan selanjutnya. Hasilnya lebih efisien, lebih rapi, lebih teratur. Lagi pula, masing-masing unsur gizi memerlukan enzim yang berbeda, masingmasing enzim juga memerlukan derajat keasaman berbeda agar mampu bekerja optimal.

\section{Asal Mula Food Combining}

Food combining bukanlah pola makan baru. Pola makan yang mirip sekali dengan food combining pernah akrab ditemui sekitar 2000 - 3000 tahun silam, sebagai kebiasaan 
suku bangsa Essene di Palestina yang terkenal memiliki umur sangat panjang. Mereka membentuk pola makan berdasarkan anjuran yang termaktub dalam kitab Taurat. Seperti tidak boleh makan roti dan daging di waktu yang bersamaan, tidak boleh makan darah, bangkai, binatang yang diharamkan seperti babi, serta binatang melata. Jauh dari kehidupan serba praktis, maka makanan yang dikonsumsi serba alami. Tidak kenal junk food, tablet, kapsul, dan sejenisnya. Bukan hanya pemilihan jenis makanan, cara makan juga diperhatikan. Mereka membiasakan diri untuk berpuasa dan tidak makan secara berlebihan.

Tahun 1900-an awal, ahli bedah terkenal dari Amerika Serikat bernama Dokter Hay, mempopulerkan kembali pola makan yang pernah dilakukan bangsa Essene dahulu. Bermula dari kecemasan yang dialaminya karena komplikasi, food combining menjadi populer sebagai pilihan yang tidak rumit. Di usia 41 tahun, Hay sudah terserang beberapa penyakit kronis seperti Crohn (sejenis penyakit ginjal akut), pembesaran jantung, tekanan darah tinggi, serta obesitas hingga berat badannya nyaris $100 \mathrm{~kg}$. Segala metode diet, penyembuhan, dan pola makan ia tekuni, namun tidak satu pun usaha berperan signifikan. Akhirnya ia menerapkan pengobatan secara alamiah. Melakukan pola hidup dan pola makan natural berdasar fitrah. Ia rutin berpuasa, serta melakukan metode pemisahan makanan.

Setelah melewati sekian kali perkembangan, metode pemisahan makanan yang dipopulerkan Dokter Hay, sekarang dikenal dengan nama "Food combining". Hay membuktikan sendiri keberhasilan metode alamiah tersebut. Tiga bulan rutin melakukannya, penyakit-penyakit yang dialaminya berangsur hilang. Berat badannya berkurang hingga 24 kg. Walau nama Hay akrab dengan food combining, tapi ia bukanlah pionir dalam penemuan metode ini. Hay menyadur rujukan dari beberapa ahli sebelumnya yang pernah meneliti tentang pencernaan. Hingga kini, sudah jutaan orang memperoleh manfaat sehat tanpa obat lantaran food combining.

\section{Makan Harus Berkualitas}

Pertanyaan ini mungkin sangat klasik. Mana yang kita pilih, makan untuk hidup atau hidup untuk makan? Tentu senada kita memilih kalau makan untuk hidup. Jika itu pilihan mutlak, artinya makan harus berkualitas agar hidup pun berkualitas. Tidak sekadar enak dan kenyang. Oleh karena itu, dari asupan dan pola makan yang kita rutinkan, harapannya bisa memperoleh serta menjaga keadaan homeostatis. Homeostatis adalah kondisi ideal saat fungsi seluruh bagian tubuh berjalan optimal. Efeknya, dalam tubuh kita minim bahkan tidak ada gangguan pada psikologis (mental), fisiologis (fungsi organ dan sistem), dan anatomis (fungsi muskuloskeletal). 
Berbeda dengan pola makan atau jenis diet lainnya, food combining sama sekali tidak mengurangi jatah makan. Aturan-aturan yang diterapkan tidak harus membuat kita mati-matian menahan lapar karena perut keroncongan. Jatah makan sama seperti biasa tapi efeknya tetap sehat dan singset. Bandingkan dengan pola makan atau janis diet lainnya, misalnya DASH (Dietary Approaches to Stop Hypertension) yang memaksa pelaku diet mematok asupan garam maksimal hanya $2.300 \mathrm{mg}$ per hari, lemak jenuh maksimal $6 \%$, dan karbohidrat hanya 55\% dari asupan normal. Tentunya jadi masalah besar, terlebih bagi yang belum terbiasa.

Penerapan food combining sederhana dan tidak perlu runyam. Sesuai namanya, food combining hanya usaha mengombinasikan atau menggabungkan makanan agar lebih mudah dicerna. Makanan mana yang lebih dahulu dimakan, yang terakhir dimakan, atau dimakan bersamaan, serta menentukan banyaknya dan waktu yang sesuai untuk makan. Pengombinasian ini ternyata berdampak baik bagi sistem pencernaan. Akibat penerapan pola yang cermat seperti mengurangi konsumsi makanan komplek (pati dan protein) secara bersamaan, maka beban kerja organ pencernaan berkurang. Semakin tidak diforsir, organ pencernaan semakin terjaga kesehatannya. Jika kita mampu menerapkan food combining dengan cermat, maka akan terhindar dari penyakit kronis seperti gangguan hati, diabetes mellitus, hipertensi, jantung, kanker colon, dan penyakit lainnya yang bersumber dari gangguan pencernaan.

\section{Food Combining Itu Gampang}

"Mau sehat saja rumit!" Kata-kata ini sama sekali tidak akan kita jumpai saat menerapkan food combining. Asal terbiasa pada keteraturan, mudah-mudahan tidak menemui kesulitan karena alasan syarat ini dan itu. Makanan sehat ada dimana-mana, tidak mesti mahal, mewah, dan tidak mesti ukur ini dan ukur itu. Justru banyak makanan mewah dan mahal yang menjadi biang penyakit. Jika kita mampu mengilhami sisi baik jenis dan cara makan sejak zaman nenek moyang dahulu hingga sekarang, tentu tidak ada kesulitan untuk sekadar hidup sehat. Tidak perlu bayar mahal biaya konsultasi demi bertanya perkara makan.

Meskipun dibarengi kecermatan dalam memilih makanan, menentukan waktu makan, dan tata cara memakannya, tapi food combining dilakukan dengan amat natural. Sebagai awalan, kita harus mengetahui secara garis besar jenis makanan berdasarkan unsurnya.

a. Pati. Kita lebih sering mengartikannya sebagai karbohidrat yang berfungsi menambah tenaga serta unsur yang mudah membuat perut kenyang. Pati sering disalahartikan 
sebagai penyebab penyakit serius seperti obesitas dan diabetes. Padahal itu hanya terjadi jika kurang cermat, seperti makan kebanyakan dan proses pengolahan yang berlebihan.

b. Protein. Protein berfungsi sebagai pembentuk sel dalam tubuh. Ada dua jenis protein yang kita kenal, yaitu protein hewani dan nabati. Kebanyakan orang Indonesia cenderung masih menganggap sebelah mata protein nabati, sebenarnya proses pencernaan protein nabati tidak sesukar protein hewani yang nyatanya menghemat energi untuk proses pencernaan. Lagi pula, sebelum dikonsumsi protein hewani harus diolah dalam suhu tinggi yang mengakibatkan asam amino dalam protein rusak.

c. Sayuran. Segudang manfaat sayuran tidak usah diragukan. Bermata bening dan mempunyai penglihatan tajam berkat rajin makan sayur. Sayuran yang kaya serat mampu memudahkan pencernaan. Jika diolah dan dikonsumsi benar, sayuran mampu menciptakan keadaan homeostatis dan menetralisir $\mathrm{pH}$ (potensial Hydrogen). Lantaran banyak sebab, pengolahan sayur justru berlebihan sehingga segudang manfaatnya tidak dirasakan.

d. Buah. Sama seperti sayuran, manfaatnya juga segudang. Asalkan cermat saat mengkonsumsinya. Seringkali buah tidak sesuai jika dipadukan dengan protein dan sayur. Buah yang cenderung lunak tidak tepat jika dipadukan dengan sayur kaya serat. Kandungan gula dalam buah juga bisa merusak protein dan lemak. Asumsi kebanyakan orang Indonesia masih salah karena menganggap buah sebagai pencuci mulut yang dikonsumsi setelah makan. Buah justru sangat baik jika dikonsumsi sebelum makan atau saat perut masih kosong.

Dari empat jenis unsur tersebut, pasti ada kombinasi-kombinasi yang dianjurkan dan yang dilarang. Tentu ada alasan ilmiahnya. Jika dianjurkan, maka unsur-unsur gizi tersebut boleh dimakan dalam waktu bersamaan. Jika dilarang, maka tidak boleh dimakan dalam waktu bersamaan.

Protein hewani tidak pas jika dikombinasikan dengan pati karena enzim pencerna keduanya berbeda. Karbohidrat dicerna oleh enzim amilase, sedangkan protein oleh enzim pepsin. Kombinasi protein hewani dengan sayuran adalah yang dianjurkan. Serat pada sayur membantu melancarkan proses pencernaan protein hewani yang agak rumit. Keduanya juga bekerjasama dalam menetralkan derajat keasaman atau $\mathrm{pH}$. Menggabungkan pati dengan sayuran juga kombinasi yang dianjurkan. Sisi negatif pati bisa teratasi oleh sayuran yang kaya serat. Sayuran mampu memberi rasa kenyang sehingga mengurangi konsumsi pati.

Kecermatan selanjutnya, kita harus paham fase yang terjadi dalam sistem pencernaan guna jadwal jadwal yang tepat untuk makan. Pukul berapa saja pencernaan lebih 
cocok bekerja dan pukul berapa ia lebih cocok beristirahat serta melakukan pembersihan. Supaya memahami fase-fase tersebut, bisa kita ketahui melalui ritme biologis atau lebih sering disebut Circadian Rhythm.

Berdasarkan ritme biologis, pencernaan bekerja aktif dari pukul 12.00 hingga pukul 20.00. Di waktu ini adalah saat yang tepat untuk melakukan aktifitas makan, khususnya makan makanan berat. Pukul 20.00 hingga pukul 04.00 pencernaan berada pada fase penyerapan. Pencernaan melakukan penyerapan energi, perbaikan sel dan jaringan, juga yang lainnya. Maka butuh energi yang banyak. Agar pasokan energi tersebut tercukupi, aktifitas manusia harus diminimalisir. Untungnya fase ini sejalan dengan waktu tidur normal manusia. Jika pada fase penyerapan kita masih sibuk untuk makan makanan berat atau bergadang, akibatnya akan ada gangguan kesehatan. Fase selanjutnya adalah pembersihan yang terjadi pukul 04.00 hingga pukul 12.00. Kotoran-kotoran sisa proses pencernaan secara alamiah terkonsentrasi untuk keluar. Bukan rahasia lagi, itu sebabnya mengapa pada pagi hari, sebagian besar dari kita merutinkan diri untuk membuangnya.

\section{Makan Aman dan Nyaman}

Pasti tidak mudah bagi pemula untuk melakukan food combining sebelum merutinkannya saban hari. Apalagi di Indonesia. Masih banyak kebiasaan saat makan yang belum sesuai tatanan. Masih banyak yang suka makan makanan berat sambil bergadang pada waktu dinihari. Masih banyak yang menganggap buah sebagai pencuci mulut. Masih banyak yang menganggap kalau tidak pakai nasi belum makan namanya. Dari bahasan-bahasan sebelumnya, adab yang demikian tentu tak sejalan dengan upaya mengejar homeostatis. Maka, semaksimal mungkin kita lanjutkan perjuangan, yakni mengamalkannya setelah kita tahu dari bahasan-bahasan sebelumnya.

Agar pola makan senantiasa aman, nyaman, dan pastinya mendukung kesehatan, harus disepadankan dengan aturan-aturan saat di meja makan. Kita mesti menyediakan waktu khusus untuk makan sekitar 25 sampai 30 menit. Makan harus dalam posisi duduk, tidak sambil berdiri dan jalan-jalan. Jumlah kunyahan pun dihitung. Agar optimal, makanan dikunyah antara 30 sampai 70 kali. Kita tidak boleh mendorong makanan menggunkan minuman karena bisa mengganggu kinerja asam lambung. Selanjutnya, santun dan anggun saat makan. Bukan berarti jaim, tapi tidak terburu-buru meninggalkan tempat makan ketika sudah selesai makan. Yang terakhir, ada nasihat orang-orang tua dahulu yang sangat layak kita sepakati. Mereka bilang kalau makan pakai sendok jangan sampai terdengar suara dentingan piring. Makan harus rapi, lembut, dan sesantun mungkin agar menuai manfaat. 


\section{Referensi}

Ma'ruf, Amar. 2014. Move On. Forthisa Karya

Ma'ruf, Amar. Natural. Forthisa Karya

Ma'ruf, A. Author Archives: Artikel HMPPI.

Ma'ruf, A. (2017). Diversitas Tanaman Obat-obatan Di Kabupaten Asahan.

Ma'ruf, Amar. Nurlaila, Anna. Sartik, Resa. 2015. Walau Pensiunan Tapi Tetap Gajian.

Cemerlang Publishing

Sakhi, Andari. Sanis, Amar. 2015. Hidup 100 Tahun Dengan Food Combining. Trans Idea Publishing 